\title{
Antimicrobial susceptibility of Salmonella Gallinarum and Salmonella Pullorum isolated from ill poultry in Brazil
}

\author{
Suscetibilidade a antimicrobianos de Salmonella Gallinarum e Salmonella \\ Pullorum isolados de aves doentes no Brasil
}

\begin{abstract}
Rafael Antonio Casarin Penha Filho ${ }^{\mathrm{I}, \mathrm{II}^{*}}$ Joseane Cristina Ferreira $^{\mathrm{III}}$ Ana Maria Iba Kanashiro ${ }^{\mathrm{IV}}$ Ana Lúcia da Costa Darini ${ }^{I I I}$ Angelo Berchieri Junior ${ }^{I}$
\end{abstract}

\section{ABSTRACT}

Salmonella Gallinarum (S. Gallinarum) and Salmonella Pullorum (S. Pullorum) are poultry host-specific, agents of fowl typhoid and pullorum disease, respectively. These biovars cause septicemic infections, resulting in high mortality. Outbreaks are frequently reported worldwide, causing losses due to the elimination of infected flocks and treatments. The use of antimicrobial agents is frequent in poultry farms to prevent or treat gastrointestinal infections. In the present research it was evaluated the antimicrobial susceptibility of $50 \mathrm{~S}$. Gallinarum and S. Pullorum isolates, from outbreaks that occurred between 1987 to 1991 and 2006 to 2013. The comparison of the susceptibility profiles showed that all isolates were susceptible to $\beta$-lactams. All isolates from 1987-1991 were susceptible to all antibiotics tested except NAL and CIP (78\%). The susceptibility profile of $\boldsymbol{S}$. Gallinarum (2006 - 2013 period) was the following NAL (58\%), CIP (63\%), ENR (67\%), TET (92\%), FFC (96\%) and SXT (96\%). S. Pullorum isolates (2006 - 2013 period) showed the following susceptibility rates to NAL (65\%), CIP (71\%), ENR (94\%) and TET (94\%). All isolates were susceptible to $\beta$-lactams tested, however, resistance to quinolones and fluoroquinolones increased over time. Furthermore, low levels of resistance to other antibiotics were found in recent isolates, such as tetracyclines.

Key words: quinolones, chicken, fowl typhoid, antimicrobial susceptibility, Salmonella.

\section{RESUMO}

Salmonella Gallinarum (S. Gallinarum) e Salmonella Pullorum (S. Pullorum) são patógenos hospedeiro-especifico de aves, agentes do tifo aviário e pulorose, respectivamente. Estes biovares causam infecções septicêmicas, resultando em alta mortalidade. Surtos são frequentemente relatados em diversos países, causando prejuízos devido à eliminação de lotes infectados e tratamentos. Agentes antimicrobianos são utilizados frequentemente em granjas avicolas para prevenir ou tratar infecções gastrointestinais. No presente trabalho, foi avaliada a susceptibilidade antimicrobiana de 50 isolados de $\boldsymbol{S}$. Gallinarum e S. Pullorum, obtidos durante surtos que ocorreram entre 1987 a 1991 e entre 2006 a 2013. A comparação dos perfis de sensibilidade mostrou que todas as amostras são sensíveis aos B-lactâmicos. Todos os isolados de 1987-1991 foram sensiveis a todos os antibióticos testados, exceto NAL e CIP (78\%). O perfil de susceptibilidade de $\boldsymbol{S}$. Gallinarum (surtos de 2006 a 2013) foi NAL (58\%), CIP (63\%), ENR (67\%), TET (92\%), FFC (96\%) e SXT (96\%). Isolados de S. Pullorum (surtos de 2006 a 2013) apresentaram as seguintes taxas de sensibilidade: NAL (65\%), CIP (71\%), ENR (94\%) e TET (94\%). Todas as amostras foram sensiveis ao $\beta$-lactâmicos testados, no entanto, a resistência às quinolonas e fluoroquinolonas aumentou ao longo do tempo. Além disso, baixos niveis de resistência a outros antibióticos foram encontrados em isolados recentes, tais como as tetraciclinas.

Palavras-chave: quinolonas, galinhas, tifo aviário, suscetibilidade antimicrobiana, Salmonella.

\section{INTRODUCTION}

Salmonella enterica serovar Gallinarum biovar Gallinarum ( $\boldsymbol{S}$. Gallinarum) causes fowl typhoid in commercial poultry, a disease characterized by acute systemic infection, with mortality rates reaching $80 \%$ of affected poultry flocks at any age. $\boldsymbol{S}$. enterica serovar Gallinarum biovar Pullorum ( $\boldsymbol{S}$. Pullorum) causes pullorum disease, which is a severe

IFaculdade de Ciências Agrárias e Veterinárias de Jaboticabal, Universidade Estadual Paulista (UNESP), 14884-900, Jaboticabal, SP, Brasil. E-mail: rafaelpenha12@yahoo.com.br. "Corresponding author.

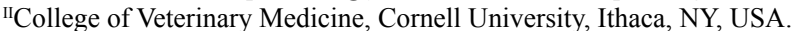

IIIFaculdade de Ciências Farmacêuticas de Ribeirão Preto, Universidade de São Paulo (USP), Ribeirão Preto, SP, Brasil

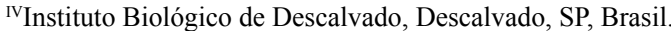


septicemic disease that causes high morbidity and mortality in young birds, specially newly hatched chicks, causing high losses to the poultry producers (SHIVAPRASAD 2000).

Both biovars cause host-specific infections in birds. The incidence of these bacteria in hatcheries and farms is controlled by biosecurity, cleaning and disinfection of the facilities (SHIVAPRASAD 2000). Vaccination is also used to prevent these diseases (LEE et al. 2005). However, due to failures in biosafety measures or ineffective immunization, outbreaks in commercial flocks are often reported worldwide (PULIDO-LANDINEZ et al. 2014; O.I.E. 2015).

The antibiotic treatment for fowl typhoid and pullorum disease in Brazil is only allowed for commercial egg layer-hens and meat producing broilers and not accepted for breeder lines, being necessary to eliminate infected flocks (BRASIL 2003). The preventive use of antimicrobial drugs such as $\beta$-lactams, aminoglycosides and fluoroquinolones has been largely applied in the poultry industry to control intestinal infections or to treat systemic bacterial infections, including those ones caused by $\boldsymbol{S}$. Gallinarum and $\boldsymbol{S}$. Pullorum in commercial chickens. Both biovars can persist in the host, with no signs of the disease in surviving birds or genetically resistant chickens and also survive in the environment for long periods. Thus, these bacteria are able to cause recurrent infections in flocks, even after therapy (SHIVAPRASAD 2000; WIGLEY et al. 2001; LEE et al. 2005).

The continuous use of antimicrobial drugs in poultry production has contributed to the emergence and maintenance of resistance genes and resistant bacteria in the poultry environment (TOLLEFSON and MILLER 2000; LIEBANA et al. 2013). Many studies have reported resistance to antibiotics in paratyphoid serovars of Salmonella spp. isolated from food producing animals (CLEMENTE et al. 2013; DE JONG et al. 2014). Although, $\boldsymbol{S}$. Gallinarum isolated from chickens in Tunisia, were recently reported to be susceptible to all drugs tested (TURKI et al. 2014), other studies about the antimicrobial susceptibility profile of animal host-specific Salmonella serovars are still scarce.

Evaluation of susceptibility to fluoroquinolones of $\boldsymbol{S}$. Gallinarum from outbreaks in Korea, showed no resistance to this class of antibiotics in isolates from 1995, however isolates from 2001 showed reduced susceptibility to enrofloxacin, ciprofloxacin, norfloxacin and ofloxacin (LEE et al. 2004).
Resistance to quinolones can be based on chromosomal mutations besides plasmids carrying resistance genes (MARTINEZ-MARTINEZ et al. 1998; RUIZ 2003; JACOBY 2005). Plasmidmediated quinolone resistance (PMQR) can favor the selection of resistant bacterial strains in environments with antibiotic use. First PMQR reports occurred during the 1990s (MARTINEZ-MARTINEZ et al. 1998) and were described as accessory mechanisms that could increase the levels of quinolone resistance when associated to chromosomal mutations in bacteria (ROBICSEK et al. 2006). The main PMQR genes circulating are qnrA, qnrB, qnrS and aac(6')$\mathrm{Ib}$-cr, which produce pentapeptide proteins capable to cause resistance to quinolones by protecting the antimicrobial target protein, type II DNA topoisomerases (RODRIGUEZ-MARTINEZ et al. 2011). Expression of these genes alone, usually confers low levels of quinolone resistance, but it may increase the selection of resistance mechanisms, leading to the emergence of high-level quinoloneresistant bacteria (STRAHILEVITZ et al. 2009; TAMANG et al. 2011).

In the present research, it was evaluated the susceptibility of $\boldsymbol{S}$. Gallinarum and $\boldsymbol{S}$. Pullorum isolates collected from infected chickens in Brazil to different classes of antimicrobial drugs, including $\beta$-lactams and quinolones, used currently or in the past in animal production. Furthermore, the results were evaluated, comparing the susceptibility profiles among isolates from the period of 1987 to 1991 with isolates from 2006 to 2013. Additionally, the presence of genes associated with PMQR were investigated by $\mathrm{PCR}$ in quinolone resistant isolates.

\section{MATERIALS AND METHODS}

Bacterial isolates

A total of $32 \boldsymbol{S}$. Gallinarum and $18 \boldsymbol{S}$. Pullorum were used in the present study. These bacteria were isolated from poultry showing clinical symptoms of these diseases, from South, Southeast and Midwest regions. The isolates were kept frozen at $-80 \mathrm{C}$, in the bacterial stocks at the School of Agricultural and Veterinary Sciences - UNESP (Jaboticabal, SP) and at the Instituto Biológico (Descalvado, SP). Isolation and identification were performed as described by (WIGLEY et al. 2005), briefly liver and spleen samples were collected from ill chickens with sterile swabs and incubated at 37C for $24 \mathrm{~h}$ in selenite broth. After incubation the enriched swabs were plated on McConkey and XLT4 agar and incubated at $37 \mathrm{C}$ for $24 \mathrm{~h}$. Suggestive Salmonella spp. 
colonies were sent to the Instituto Adolfo Lutz, SP, for serotyping according to the White-KauffmanLe Minor scheme (POPOFF 2001) and stored at $-80 \mathrm{C}$ in LB broth containing $50 \%$ Glycerol. The confirmed isolates were divided in three groups for analysis, the first group consisted of 9 isolates $(8 \boldsymbol{S}$. Gallinarum and $1 S$. Pullorum) collected during the period of 1987 to 1991, the second consisted of 24 $\boldsymbol{S}$. Gallinarum isolates and the third group consisted of $17 \mathrm{~S}$. Pullorum isolates. The last two groups of samples were collected from 2006 to 2013.

Antimicrobial susceptibility

The $\boldsymbol{S}$. Gallinarum and $\boldsymbol{S}$. Pullorum isolates were spread on the surface of Muller Hinton agar plates. The susceptibility test was performed by agar disk diffusion method using beta-lactams amoxillin/ clavulanic acid (AMC 20/10 $\mu^{-1}$ ), cefotaxime

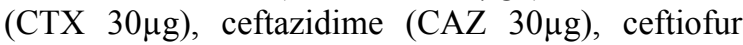

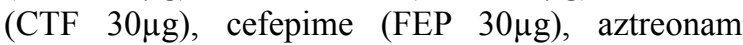

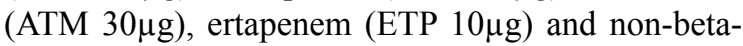
lactams, nalidixic acid (NAL 30 $\mu \mathrm{g}$ ), ciprofloxacin (CIP $5 \mu \mathrm{g}$ ), enrofloxacin (ENR $5 \mu \mathrm{g}$ ), tetracycline (TET $30 \mu \mathrm{g}$ ), trimethoprim-sulfamethoxazole (SXT $1.25 / 23.75 \mu \mathrm{g}$ ), chloramphenicol (CHL 30 $\mu \mathrm{g}$ ) and

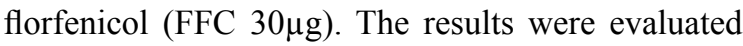
according to the Clinical Laboratory Standards Institute recommendations (CLSI 2002; CLSI 2013) considering the intermediate as resistant. Escherichia coli ATCC 25922 was used as quality control.

\section{Detection of PMRQ determinants}

Isolates exhibiting breakpoint indicative of resistance to NAL or CIP were screened by PCR for detection of the following PMQR genes, qnrA, qnrB, qnrS, and acc(6')-Ib-cr genes. Screening of PMQR determinants was carried out by multiplex PCR with primers for qnrA gene, F (5'-AGAGGATTTCTCACGCCAGG-3') and $\mathrm{R}$ (5'-TGCCAGGCACAGATC-TTGAC-3') amplifying a $580 \mathrm{bp}$ product; primers for $\mathrm{qnrB}$ gene, F (5'-GGMATHGAAATTCGCCACTG-3') and $\mathrm{R}$ (5'-TTTGCYGYYCGCCAGT-CGAA-3') to amplify $264 \mathrm{bp}$ and primers for qnrS gene, $\mathrm{F}$ (5'-GCAAGTTCATTGAACAGGGT-3') and R (5'-TCTAAACCGTCGAGTTCG-GCG-3') to amplify $428 \mathrm{bp}$. The PCR reaction was performed using the following cycling profile: 10 minutes at $95^{\circ} \mathrm{C}$ and 30 cycles of 1 minute at $95^{\circ} \mathrm{C}, 1$ minute at $54^{\circ} \mathrm{C}$, 1 minute at $72^{\circ} \mathrm{C}$ and 10 minutes at $72^{\circ} \mathrm{C}$ for the final extension (CATTOIR et al. 2007). Another PCR was done to search aac $\left(6^{\prime}\right)$-Ib-cr gene using the primers $\mathrm{F}$ (5'-TTGCGATGCTCTATGAGTGGCTA-3') and R
(5'-CTCGAATGC-CTGGCGTGTTT-3'), to amplify 482 bp (MINARINI et al. 2008).

\section{Statistical analysis}

Statistical difference for resistance levels to each antimicrobial was compared between the recent isolates (2006-2013) with isolates from the period of 1987-1991. Data from the antimicrobial susceptibility tests were analysed by the nonparametric chi-square method using 5\% significance level.

\section{RESULTS}

All $\boldsymbol{S}$. Gallinarum (8/8) and $\boldsymbol{S}$. Pullorum $(1 / 1)$ isolated between 1987 and 1991 were susceptible to beta-lactams AMC, CTX, CAZ, FEP, ATM, ETP, CTF and to the non-beta-lactams ENR, TET, CHL, FFC and SXT. Among these isolates, the susceptibility to the quinolone NAL and to the fluoroquinolone CIP was 78\% (7/9), being only $1 S$. Pullorum isolate and $1 \boldsymbol{S}$. Gallinarum isolate resistant to those antibiotics.

All $\boldsymbol{S}$. Gallinarum isolates from 2006 to 2013 (24/24) were susceptible to beta-lactams AMC, CTX, CAZ, FEP, ATM, ETP, CTF, although, the percentage of isolates susceptible to the non-betalactams were noticed as follows: NAL $(58 \% ; 14 / 24)$, CIP $(63 \% ; 15 / 24)$, ENR $(67 \% ; 16 / 24)$, TET (92\%; $22 / 24)$, CHL $(100 \% ; 24 / 24)$, FFC $(96 \% ; 23 / 24)$ and SXT $(96 \% ; 23 / 24)$ (Figure 1).

The results of the susceptibility test of $S$. Pullorum isolates collected from 2006 to 2013 are shown in figure 1. All isolates (17/17) demonstrated susceptibility to the beta-lactams AMC, CTX, CAZ, FEP, ATM, ETP, CTF and to CHL, FFC and SXT. However, among these isolates, susceptibility to other non-beta-lactams were the following: NAL $(65 \% ; 11 / 17)$, CIP $(71 \% ; 12 / 17)$, ENR $(94 \% ; 16 / 17)$ and TET $(94 \% ; 16 / 17)$.

The PCR screening for the PMQR genes qnrA, qnrB, qnrS, and acc(6')-Ib-cr showed that none of these resistance genes was present in any $\boldsymbol{S}$. Gallinarum or $\boldsymbol{S}$. Pullorum isolates.

\section{DISCUSSION}

Fowl typhoid and pullorum disease are controlled by biosecurity and vaccination by the poultry industry, however, these bacteria are still present in the poultry environment and outbreaks are often reported worldwide (O.I.E. 2015). Considering the epidemiology involved in $\boldsymbol{S}$. Gallinarum and $\boldsymbol{S}$. Pullorum infections, characterized by the spread of 


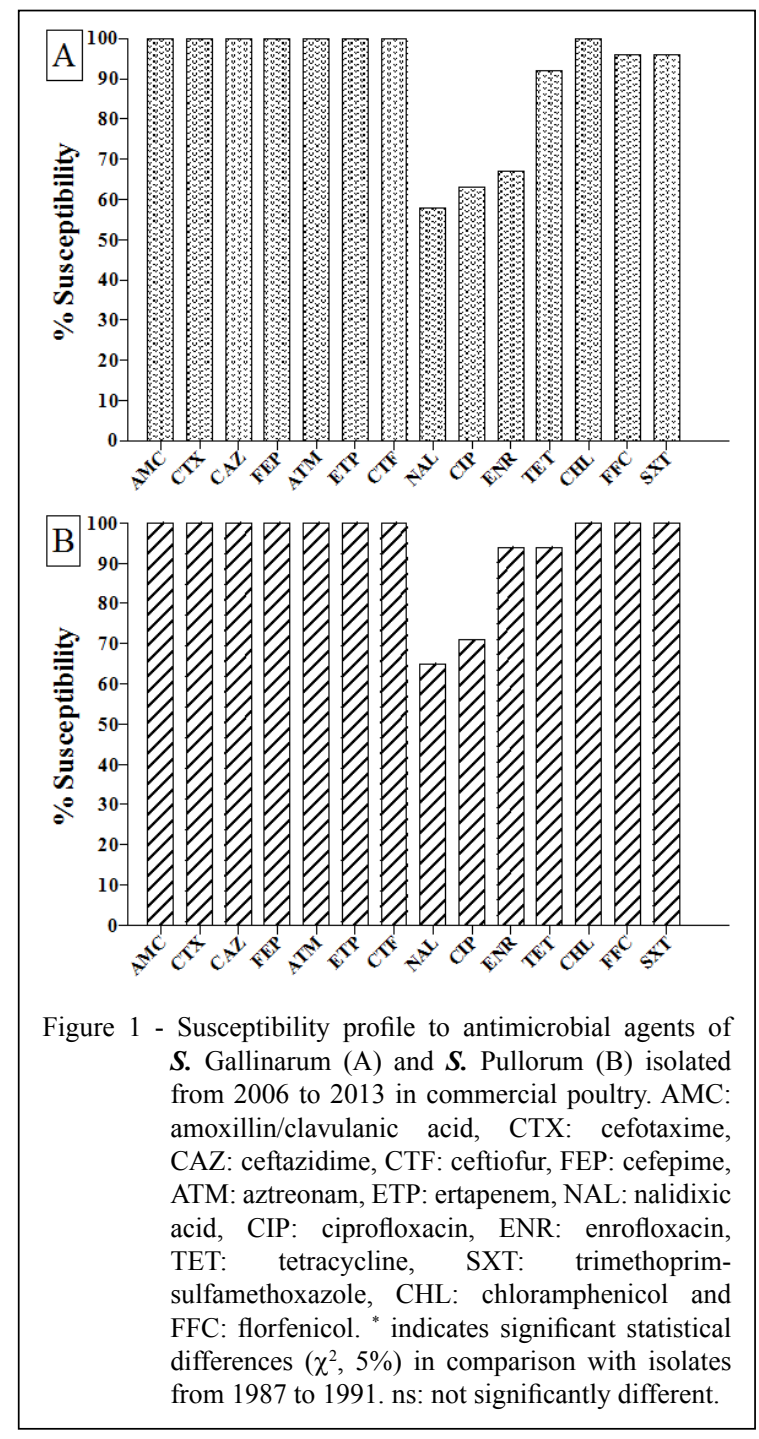

these bacteria within different flocks and the possible carrier state in chickens (SHIVAPRASAD 2000), the use of prophylactic doses may cause selection of drug-resistant strains (SILLEY et al. 2011; LIEBANA et al. 2013; DE JONG et al. 2014).

The present study assessed and compared the susceptibility to critically important classes of antibiotics such as quinolones, fluoroquinolones and beta-lactams of isolates collected during 1987 to 2013. All $\boldsymbol{S}$. Gallinarum and $\boldsymbol{S}$. Pullorum isolated from 1987 to 1991 were susceptible to 12 out of 14 antimicrobial drugs, including the beta-lactams tested in this study. However, $78 \%$ were susceptible to the quinolone $\mathrm{NAL}$ and to the fluoroquinolone CIP. The quinolones and fluoroquinolones are frequently elected drugs for treatment and prevention of Salmonella infections. The increased resistance to nalidixic acid has been attributed before to the use of enrofloxacin (DAVIES et al. 1999). However, in the present study the isolates from 1987 to 1991 that were nalidixic acid and ciprofloxacin resistant, showed susceptibility to enrofloxacin. These results show lower resistance levels for the older isolates. In comparison with older isolates, $\boldsymbol{S}$. Gallinarum and $\boldsymbol{S}$. Pullorum from 2006 to 2013 showed diverse phenotypes, with resistance to the antimicrobial agents, NAL, CIP, ENR, TET, FFC and SXT (Figure 1). The increasing resistance in enterobacteria could be attributed to the presence of conjugative plasmids carrying resistance genes in the environment (LIEBANA et al. 2013). However, the search for PMQR genes in these isolates did not show the presence in any isolate. Thus, the resistance to quinolone noticed in these isolates might be caused by mutations in the drug target enzymes or increased expression of efflux system (JACOBY 2005).

In South Korea, no resistance to fluoroquinolones was detected in $\boldsymbol{S}$. Gallinarum isolates from chickens from 1995 (LEE et al. 2004), however a number of isolates from 2001 were reported resistant to fluoroquinolones showing an increased MIC that ranged from 2 to $8 \mu \mathrm{g} / \mathrm{ml}$ (KANG et al. 2010). Our results also suggest an increasing resistance to this class of antibiotics, especially in $\boldsymbol{S}$. Gallinarum which was statistically different from the levels detected in older isolates $(\mathrm{P}<0.05)$. Despite the resistance noticed in $S$. Pullorum from the period of 2006-2013 was not statistically different from older isolates $(\mathrm{P}>0.05)$ it is important to notice that novel resistance was detected in the recent isolates that were not present in the bacteria from 1987-1991, such as ENR and TET (Figure 1).

All isolates of both biovars $\boldsymbol{S}$. Gallinarum and $\boldsymbol{S}$. Pullorum evaluated in the present study were susceptible to the $\beta$-lactam class of antibiotics, even those more recently isolated, from 2006 to 2013. Even though the isolates may show susceptibility to first and second generation cephalosporins, aminoglycosides or cephamycins in vitro, these drugs have no activity against Salmonella sp in vivo (CLSI 2013).

Antibiotics are usually incorporated with feed or water and administered to animals to prevent gastrointestinal infections that interfere with nutrient absorption and weight gain in animals (DE JONG et al. 2014). Many studies report an increasing resistance to $\beta$-lactams in paratyphoid Salmonella enterica and $\boldsymbol{E}$. coli isolated from humans and animals (MARANO et al. 2000; CLEMENTE et al. 2013; LIEBANA et al. 2013; FERREIRA et al. 2014). S. Gallinarum and $\boldsymbol{S}$. Pullorum are hostspecific biovars that invade quickly through the 
intestinal mucosa colonizing the internal organs, such as spleen and liver, the elected sites for bacterial survival and replication (WIGLEY et al. 2001). This characteristic differentiates the typhoid biovars from the paratyphoid and other non-invasive enterobacteria. The invasive nature of these biovars limits its contact with enterobacteria, which may hamper or decrease the chances of horizontal transfer of resistance genes and plasmids in the intestinal lumen environment.

The administration of enrofloxacin was shown to select resistant enterobacteria and is inefficacious to eliminate Salmonella from internal organs (HUMBERT et al. 1997; BARROW et al. 1998). In many countries the control of salmonellosis in poultry is not performed with antibiotics because of the poor history of these drugs in eliminating Salmonella colonization and due to the risks by promoting and selecting resistant strains in the fields (CASTANON 2007).

Overall, this research has evaluated the susceptibility profile of $\boldsymbol{S}$. Gallinarum and $\boldsymbol{S}$. Pullorum isolated from 1987 to 1991 and 2006 to 2013 in Brazil. The comparison of the profiles showed no resistance to $\beta$-lactams. However, isolates from 2006 to 2013 presented higher rate of resistance to quinolones (NAL) and fluoroquinolones (CIP, ENR) and resistance to other classes of antibiotics that were not noticed in older isolates (1987-1991), such as TET, FFC and SXT. Moreover, no PMQR gene was found in these isolates.

\section{ACKNOWLEDGEMENTS}

The authors would like to thank Fundação de Anparo á Pesquisa do Estado de São Paulo (FAPESP). R.A.C.P.F. was supported by post-doctoral fellowship, FAPESP grant 2012/240177 and 2013/26122-5.

\section{REFERENCES}

BARROW, P. A., et al. Effect of enrofloxacin administration on excretion of Salmonella Enteritidis by experimentally infected chickens and on quinolone resistance of their Escherichia coli flora. Avian Pathology, v.27, n.6, p.586-590, 1998. Available from: $<$ http://dx.doi.org/10.1080/03079459808419388>. Accessed: Oct. 10, 2014. doi: 10.1080/03079459808419388.

BRASIL (2003). Ministério da Agricultura, Pecuária e Abastecimento. Programa Nacional de Sanidade Avícola. Instrução Normativa 78. Brasília - DF, Diário Oficial da União, República Federativa do Brasil. 215.

CASTANON, J. I. History of the use of antibiotic as growth promoters in European poultry feeds. Poultry Science, v.86, n.11, p.2466-2471, 2007. Available from: <http://dx.doi.org/10.3382/ps.2007-00249> Accessed: Jan. 05, 2013. doi:10.3382/ps.2007-00249.
CATTOIR, V., et al. Multiplex PCR for detection of plasmidmediated quinolone resistance $q n r$ genes in ESBL-producing enterobacterial isolates. The Journal of Antimicrobial Chemotherapy, v.60, n.2, p.394-397, 2007. Available from: $<$ http://dx.doi.org/10.1093/jac/dkm204>. Accessed: Oct 21, 2014. doi: $10.1093 / \mathrm{jac} / \mathrm{dkm} 204$

CLEMENTE, L., et al. Occurrence of extended-spectrum betalactamases among isolates of Salmonella enterica subsp. enterica from food-producing animals and food products, in Portugal. International Journal of Food Microbiology, v.167, n.2, p.221-228, 2013. Available from: <http://dx.doi.org/10.1016/j. ijfoodmicro.2013.08.009>. Accessed: Feb. 15, 2015. doi: 10.1016/j.ijfoodmicro.2013.08.009.

CLSI. (2002). Performance Standards for Antimicrobial Disk and Dilution Susceptibility Tests for Bacteria Isolated from Animals; Approved Standard-Second Edition. Wayne, PA: Clinical and Laboratory Standards Institute. CLSI Document M31-A2.

CLSI. (2013). Performance Standards for Antimicrobial Susceptibility Testing; Twenty-Third Informational Supplement. Wayne, PA: Clinical and Laboratory Standards Institute. CLSI document M100-S23.

DAVIES, R. H., et al. Nalidixic acid resistance in Salmonellae isolated from turkeys and other livestock in Great Britain. The Veterinary Record, v.144, n.12, p.320-322, 1999. Available from: <http://dx.doi.org/10.1136/vr.144.12.320> Accessed: Sept. 22, 2014. doi: 10.1136/vr.144.12.320.

DE JONG, A., et al. Antimicrobial susceptibility of Salmonella isolates from healthy pigs and chickens (2008-2011). Veterinary Microbiology, v.171, n.3-4, p.298-306, 2014. Available from: $<$ http://dx.doi.org/10.1016/j.vetmic.2014.01.030>. Accessed: Jul. 17, 2015. doi: 10.1016/j.vetmic.2014.01.030.

FERREIRA, J. C., et al. IncI1/ST113 and IncI1/ST114 conjugative plasmids carrying bla in Escherichia coli isolated from poultry in Brazil. Diagnostic Microbiology and Infectious Disease, v.80, n.4, p.304-306, 2014. Available from: $<$ http://dx.doi.org/10.1016/j. diagmicrobio.2014.09.012>. Accessed: Aug. 05 2014. doi: 10.1016/j.diagmicrobio.2014.09.012.

HUMBERT, F., et al. Bacteriological monitoring of Salmonella Enteritidis carrier birds after decontamination using enrofloxacin, competitive exclusion and movement of birds. The Veterinary Record, v.141, n.12, p.297-299, 1997. Available from: <http:// dx.doi.org/10.1136/vr.141.12.297>. Accessed: Mar. 28 2012. doi: 10.1136/vr.141.12.297.

JACOBY, G. A. Mechanisms of resistance to quinolones. Clinical Infectious Diseases, v.41 Suppl 2, p.S120-126, 2005. Available from: <http://dx.doi.org/10.1086/428052>. Accessed: Mar. 20, 2013. doi: 10.1086/428052.

KANG, M. S., et al. Characterization of antimicrobial resistance of recent Salmonella enterica serovar Gallinarum isolates from chickens in South Korea. Avian Pathology, v.39, n.3, p.201-205, 2010. Available from: $<$ http://dx.doi.org/10.1080/03079451003767 261>. Accessed: Feb. 28, 2013. doi: 10.1080/03079451003767261.

LEE, Y. J., et al. Salmonella Gallinarum gyrA mutations associated with fluoroquinolone resistance. Avian Pathology, v.33, n.2, p.251-257, 2004. Available from: <http://dx.doi.org/1 0.1080/0301945042000195759>. Accessed: May 25, 2013. doi: $10.1080 / 0301945042000195759$. 
LEE, Y. J., et al. Safety and efficacy of Salmonella Gallinarum 9R vaccine in young laying chickens. Avian Pathology, v.34, n.4, p.362-366, 2005. Available from: <http://dx.doi. org/10.1080/03079450500180895>. Accessed: Jul. 13. 2009. doi: $10.1080 / 03079450500180895$.

LIEBANA, E., et al. Public health risks of enterobacterial isolates producing extended-spectrum beta-lactamases or AmpC beta-lactamases in food and food-producing animals: an EU perspective of epidemiology, analytical methods, risk factors, and control options. Clinical Infectious Diseases, v.56, n.7, p.1030-1037, 2013. Available from: <http://dx.doi. org $/ 10.1093 / \mathrm{cid} /$ cis 1043>. Accessed: Jan. 19, 2014. doi: $10.1093 / \mathrm{cid} / \mathrm{cis} 1043$.

MARANO, N. N., et al. The National Antimicrobial Resistance Monitoring System (NARMS) for enteric bacteria, 1996-1999: surveillance for action. Journal of the American Veterinary Medical Association, v.217, n.12, p.1829-1830, 2000. Available from: <http://avmajournals.avma.org/doi/ pdf/10.2460/javma.2000.217.1812>. Accessed: Jun. 082015.

MARTINEZ-MARTINEZ, L., et al. Quinolone resistance from a transferable plasmid. Lancet, v.351, n.9105, p.797799, 1998. Available from: <http://dx.doi.org/10.1016/S01406736(97)07322-4>. Accessed: May 22, 2015. doi: 10.1016/ S0140-6736(97)07322-4.

MINARINI, L. A., et al. Plasmid-mediated quinolone resistance determinants among enterobacterial isolates from outpatients in Brazil. The Journal of Antimicrobial Chemotherapy, v.62, n.3, p.474-478, 2008. Available from: $<$ http://dx.doi.org/10.1093/jac/dkn237>. Accessed: Mar. 19 2013. doi: $10.1093 / \mathrm{jac} / \mathrm{dkn} 237$

World Organisation for Animal Health (O.I.E.). World Animal Health Information System. Available from: <http:// www.oie.int/wahis_2/public/wahid.php/Diseaseinformation/ Diseasetimelines $>$. Accessed: Jan. 15, 2015.

POPOFF, M. Y. Antigenic formulas of the Salmonella serovars, 8th ed., WHO Collaborating Center for Reference and Research on Salmonella, Institut Pasteur, Paris, France. 19, p.6823-6831, 2001. Available from: <https://www.pasteur.fr/ ip/portal/action/WebdriveActionEvent/oid/01s-000036-089>. Accessed: Jul. 01, 2015.

PULIDO-LANDINEZ, M., et al. Presence of Salmonella Enteritidis and Salmonella Gallinarum in commercial laying hens diagnosed with fowl typhoid disease in Colombia. Avian Diseases, v.58, n.1, p.165-170, 2014. Available from: <http:// dx.doi.org/10.1637/10598-062613-Case.1>. Accessed: Jun. 18, 2015. doi: 10.1637/10598-062613-Case.1.

ROBICSEK, A., et al. The worldwide emergence of plasmidmediated quinolone resistance. The Lancet: Infectious Diseases, v.6, n.10, p.629-640, 2006. Available from: <http:// dx.doi.org/10.1016/S1473-3099(06)70599-0>. Accessed: Jan. 25, 2015. doi: 10.1016/S1473-3099(06)70599-0.

RODRIGUEZ-MARTINEZ, J. M., et al. Plasmid-mediated quinolone resistance: an update. Journal of Infection and
Chemotherapy, v.17, n.2, p.149-182, 2011. Available from: $<$ http://dx.doi.org/10.1007/s10156-010-0120-2>. Accessed: Aug. 29, 2014. doi: 10.1007/s10156-010-0120-2.

RUIZ, J. Mechanisms of resistance to quinolones: target alterations, decreased accumulation and DNA gyrase protection. The Journal of Antimicrobial Chemotherapy, v.51, n.5, p.1109-1117, 2003. Available from: <http:// dx.doi.org/10.1093/jac/dkg222>. Accessed: Dec. 12, 2014. doi: $10.1093 / \mathrm{jac} / \mathrm{dkg} 222$.

SHIVAPRASAD, H. L. Fowl typhoid and pullorum disease. 19, n.2, p.405-424, 2000. Available from: <http://www.ncbi. nlm.nih.gov/pubmed/10935271>. Accessed: Mar. 13, 2015.

SILLEY, P., et al. Harmonisation of resistance monitoring programmes in veterinary medicine: an urgent need in the EU? International Journal of Antimicrobial Agents, v.37, n.6, p.504-512, 2011. Available from: <http://dx.doi.org/10.1016/j. ijantimicag.2010.12.002>. Accessed: Feb. 22, 2014. doi: 10.1016/j.ijantimicag.2010.12.002.

STRAHILEVITZ, J., et al. Plasmid-mediated quinolone resistance: a multifaceted threat. Clinical Microbiology Reviews, v.22, n.4, p.664-689, 2009. Available from: <http:// dx.doi.org/10.1128/CMR.00016-09>. Accessed: Sept. 04, 2014. doi: 10.1128/CMR.00016-09.

TAMANG, M. D., et al. Prevalence and mechanisms of quinolone resistance among selected nontyphoid Salmonella isolated from food animals and humans in Korea. Foodborne Pathogens and Disease, v.8, n.11, p.1199-1206, 2011. Available from: <http://dx.doi.org/10.1089/fpd.2011.0899>. Accessed: Aug. 19, 2013. doi: 10.1089/fpd.2011.0899.

TOLLEFSON, L. and M. A. MILLER. Antibiotic use in food animals: controlling the human health impact. Journal of AOAC International, v.83, n.2, p.245-254, 2000. Available from: $\quad<$ http://www.ncbi.nlm.nih.gov/pubmed/10772160>. Accessed: Feb. 15, 2015.

TURKI, Y., et al. Molecular typing, antibiotic resistance, virulence gene and biofilm formation of different Salmonella enterica serotypes. The Journal of General and Applied Microbiology, v.60, n.4, p.123-130, 2014. Available from: <http://www.ncbi.nlm.nih.gov/pubmed/25273985>. Accessed: Jan. 21, 2015.

WIGLEY, P., et al. Salmonella enterica serovar Pullorum persists in splenic macrophages and in the reproductive tract during persistent, disease-free carriage in chickens. Infection and Immunity, v.69, n.12, p.7873-7879, 2001. Available from: <http://dx.doi.org/10.1128/IAI.69.12.78737879.2001>. Accessed: May 11, 2014. doi: 10.1128/ IAI.69.12.7873-7879.2001.

WIGLEY, P., et al. Oral infection with the Salmonella enterica serovar Gallinarum 9R attenuated live vaccine as a model to characterise immunity to fowl typhoid in the chicken. BMC Veterinary Research, v.1, p.2, 2005. Available from: <http:// dx.doi.org/10.1186/1746-6148-1-2>. Accessed: Jun. 20, 2014. doi: $10.1186 / 1746-6148-1-2$ 